Key Biodiversity Area Special Series

\title{
Using important plant areas and important bird areas to identify Key Biodiversity Areas in the Republic of Macedonia
}

\author{
Ljupcho Melovski ${ }^{1}$, Metodija Velevski ${ }^{2}$, Vlado Matevski ${ }^{3}$, Vasko Avukatov ${ }^{4}$ \& Aleksandar Sarov ${ }^{5}$ \\ ${ }^{1,3}$ Institute of Biology, University of St. Cyril and Methodius, Blvd. Krste Petkov Misirkov bb, 1000 Skopje, Republic of Macedonia \\ 1,2,4,5 Macedonian Ecological Society, Blvd "Kuzman Josifovski Pitu" 28/3-7, 1000 Skopje, Republic of Macedonia \\ Email: ${ }^{1}$ melovski@pmf.ukim.mk (corresponding author), ${ }^{2}$ velevski@mes.org.mk, ${ }^{3}$ vladom@pmf.ukim.mk, ${ }^{4}$ avukatov@mes.org.mk, \\ ${ }^{5}$ sarov@mes.org.mk
}

Date of publication (online): 06 August 2012 Date of publication (print): 06 August 2012 ISSN 0974-7907 (online) | 0974-7893 (print)

\section{Manuscript details:}

Ms \# 02997

Received 08 November 2011

Final revised received 18 January 2012

Finally accepted 01 June 2012

Citation: Melovski, Lj., M. Velevski, V. Matevski, V. Avukatov \& A. Sarov (2012). Using important plant areas and important bird areas to identify Key Biodiversity Areas in the Republic of Macedonia. Journal of Threatened Taxa 4(8): 2766-2778.

Copyright: (c) Ljupcho Melovski, Metodija Velevski, Vlado Matevski, Vasko Avukatov \& Aleksandar Sarov 2012. Creative Commons Attribution 3.0 Unported License. JoTT allows unrestricted use of this article in any medium for non-profit purposes, reproduction and distribution by providing adequate credit to the authors and the source of publication.

For Author Details, Author Contribution and Acknowledgements see end of this article.

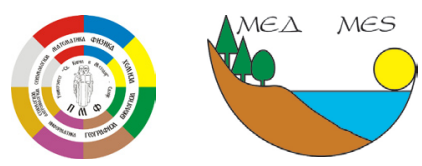

(c) (i) (ㅁ)

OPEN ACCESS | FREE DOWNLOAD
Abstract: An attempt is made to identify Key Biodiversity Areas in the Republic of Macedonia through the identification of internationally recognized important areas for biodiversity: Important Plant Areas (IPAs) and Important Bird Areas (IBAs). Forty two IPAs covering $6,495 \mathrm{~km}^{2}$ and 24 IBAs covering $6,907 \mathrm{~km}^{2}$ have been identified in Macedonia. Thirty seven IPAs $\left(6,152 \mathrm{~km}^{2}\right.$ or $24 \%$ of the country's territory) and 15 IBAs $\left(4,821 \mathrm{~km}^{2}\right.$ or $18.75 \%$ of the national territory), meet KBA criteria, between them yielding 42 KBAs. The remaining five IPAs and nine IBAs do not meet KBA criteria although have international significance. Together IPAs and IBAs total $10,698 \mathrm{~km}^{2}$; those meeting the KBA criteria total $9,670 \mathrm{~km}^{2}$. In total, $73 \%$ and $65 \%$ of the entire national protected areas (PAs) surface overlaps with IPAs and IBAs respectively. This proportion is $81 \%$ for the $42 \mathrm{KBAs}$. However, only $25 \%$ of the total size of protected areas overlaps with IPAs, only $21 \%$ overlap with IBAs, and only $19 \%$ with the combined 42 KBAs. This means that Macedonia's protected areas system is not yet representative and comprehensive for safeguarding its botanical and avian diversity.

Keywords: Important Bird Areas, Important Plant Areas, Key Biodiversity Areas, Macedonia.

Macedonian Abstract: Апстракт: Во трудот е направен обид да се идентификуваат Клучните подрачја за биодиверзитетот (КПБ) во Република Македонија преку идентификација на меѓународно признатите значајни подрачја за биодиверзитет: Значајните растителни подрачја (ЗРП) и Значајните подрачја за птици (ЗПП). Во Македонија се идентифкувани 42 ЗРП (со површина од $6.495 \mathrm{~km}^{2}$ ) и 24 ЗПП (со површина од $6.907 \mathrm{~km}^{2}$ ). Критериумите за КПБ ги задоволуваат 37 ЗРП (со површина од 6.152km² или $24 \%$ од територијата на земјата) и 153 ПП (со површина од $4.821 \mathrm{~km}^{2}$ или $18,75 \%$ од националната територија) што резултира со 42 КПБ. Останатите пет ЗРП и девет ЗПП не ги задоволуваат критериумите за КПБ иако имаат меѓународно значење. Површината на ЗРП и ЗПП вкупно изнесува $10.698 \mathrm{~km}^{2}$, додека вкупната површина на оние што ги задоволуваат критериумите за КПБ изнесува 9.670 km². Вкупно $73 \%$ и $65 \%$ од површината на заштитените подрачја на национално ниво се преклопува со ЗРП и со ЗПП соодветно. Овој сооднос изнесува 81\% за 42-те КПБ. Наспроти тоа, само $25 \%$ од вкупната површина на заштитените подрачја се преклопува со ЗРП и само $21 \%$ со ЗПП, односно само $19 \%$ со комбинираните 42 КПБ. Ова значи дека системот на заштитени подрачја во Македонија не е доволно репрезентативен и сеопфатен за да обезбеди зачувување на нејзиното растително и орнитолошко богатство.

Клучни зборови: Значајни подрачја за птици, Значајни растителни подрачја, Клучни подрачја за биодиверзитет, Македонија

The Key Biodiversity Area series documents the application of the concept and showcases the results from various parts of the world. The series is edited under the auspices of the IUCN World Commission on Protected Areas/Species Survival Commission Joint Task Force on 'Biodiversity and Protected Areas', with the editors supported by BirdLife International, Conservation International, IUCN, National Fish \& Wildlife Foundation, NatureServe, Parks Canada, and Plantlife International.

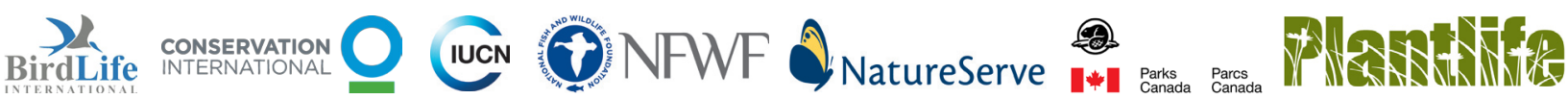




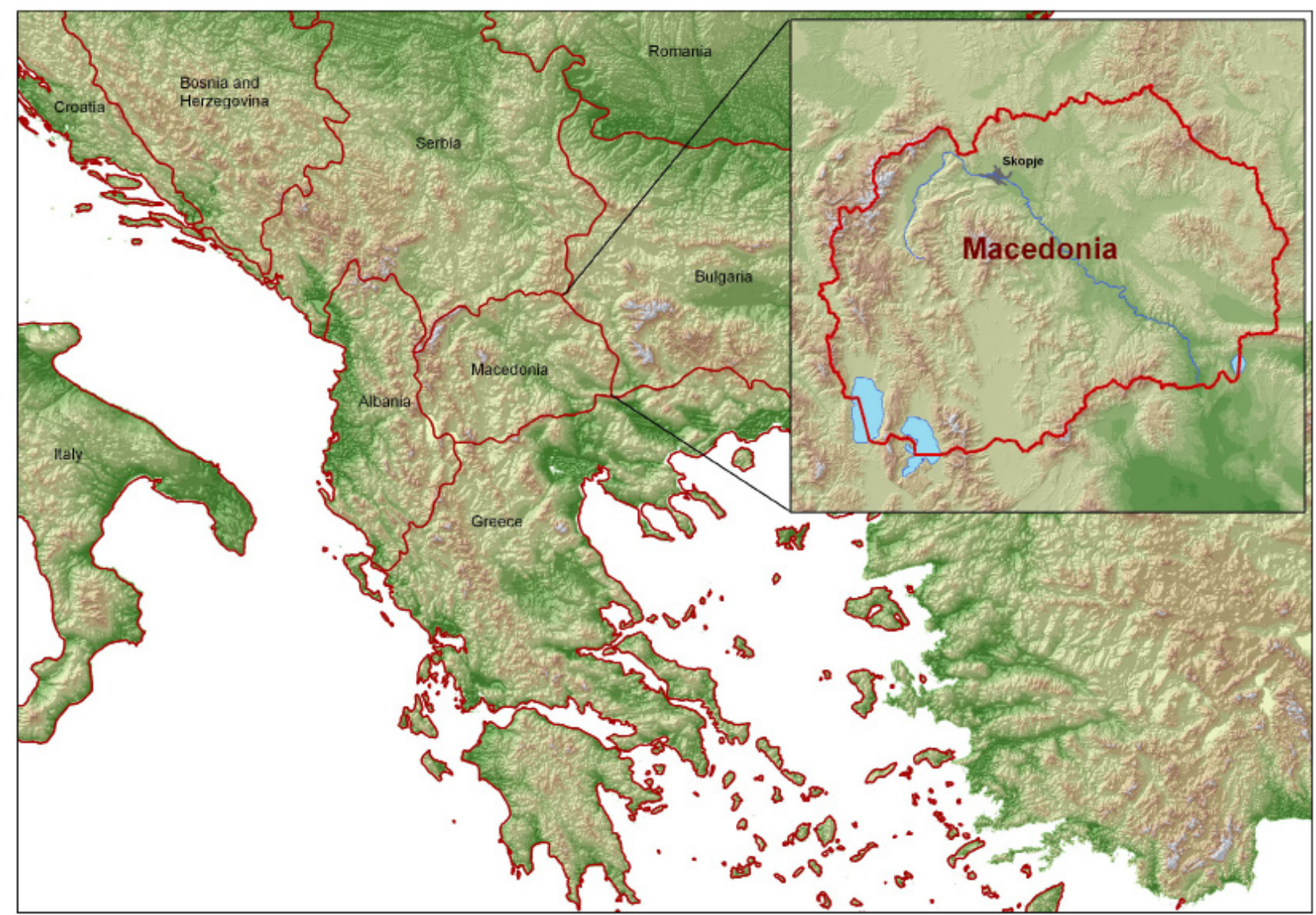

Figure 1. Republic of Macedonia and its position in the Balkan Peninsula

\section{INTRODUCTION}

Key Biodiversity Areas (KBAs) are defined as sites of global significance for biodiversity conservation, and thus are intended to capture the world's most important natural heritage. They are identified and delineated through a defined methodology (Langhammer et al. 2007), which includes to an extent, that used to identify Important Birds Areas (Heath \& Evans 2000) and Important Plant Areas (Anderson 2002).

The Republic of Macedonia covers an area of $25,713 \mathrm{~km}^{2}$ characterized by mountainous terrain in the west and east, and lowland habitats in the centre. It occupies a central position on Balkan Peninsula (Fig. 1) and contains alpine, continental sub-mediterranean and pontic steppe biogeographic zones. The valleys located in the continental biogeographic zone have a strong Mediterranean influence.

Despite its small size Macedonia has a comparatively high level of floral endemicity, and relict species in the mountains, forests and "steppes" of the lowlands. Four percent of the national flora is endemic - 114 vascular plant species (including one fern) out of a total flora of over 3,200 species. However, the number of nearendemic species (e.g. those confined to one mountain top but which occur across borders with neighbouring countries) is much greater (Kuzmanov 1979; Micevski 1985, 1993; Strid \& Tan 1991, 1997; Matevski 2010), and the percentage of near-national endemic species (defined here as having a range limited to less than $5,000 \mathrm{~km}^{2}$ within the Balkan Peninsula) is greater still. Although the flora is well studied (Micevski 1985, 1993, 1995, 1998, 2001, 2005; Matevski 2010), species new to Macedonia (even new to science) are frequently recorded. Many species reach the borders of their range in the country; the southern border for boreal and alpine species, the northern for Mediterranean species and the western border for Ponto-Caspian and Asia Minor elements. The habitat diversity is also very high, as shown by the diversity of plant communities.

Endemism is high among other groups of animals (especially fish and invertebrates). For example, Lake Ohrid is the centre of freshwater endemism in Europe (Levkov et al. 2007; Albrecht \& Wilke 2008; Levkov 
2009).

The bird fauna is insufficiently studied, with 318 species recorded so far (Micevski 2002/2003; Velevski et al. 2010). However, significant populations of some species, particularly Egyptian Vulture, Imperial Eagle and Dalmatian Pelican are found.

Although Macedonia has ratified almost all conventions on biodiversity protection ${ }^{1}$ the conservation status of plants, habitats, birds and other animal species is often not favourable. Wetlands of all types are especially threatened (Ministry of Environment and Physical Planning 2004).

The main goal of this study is to identify the most important sites for biodiversity in Macedonia, using a combination of Important Plant Areas (IPAs) and Important Bird Areas (IBAs) that have already been identified. The work also seeks to compare the criteria used for designation of IPAs and IBAs with the KBA methodology and to show the representativeness and comprehensiveness of the national protected areas system.

\section{METHODS}

This analysis of KBAs in Macedonia integrates the findings of two previous analyses of important sites for biodiversity in Macedonia; IPAs (Radford \& Odé 2009; Melovski et al. 2010) and IBAs (Velevski et al. 2010).

\section{IPAs}

IPAs were identified using European IPA criteria as developed by Plantlife International in collaboration with various international plant conservation networks (Anderson 2002). Sites containing following criteria were categorized under (i) criteria $\mathrm{A}$ based on threatened species; (ii) criteria $\mathrm{B}$ based on species-richness and endemism; and (iii) criterion $\mathrm{C}$ those containing threatened habitats. The IPA criteria overlap to an extent with those used to identify KBAs sensu Langhammer et al. (2007) and the current analysis has focused on

\footnotetext{
${ }^{1}$ Convention on the protection of the World's Cultural and Natural Heritage, Convention on Wetlands of International Importance, Convention on the Conservation of European Wildlife and Natural Habitats, Convention on Biological Diversity, Convention on International Trade in endangered Species of Wild Fauna and Flora, Convention on the Conservation of Migratory Species of Wild Animals, Agreement on the Conservation of Bats in Europe, Agreement on the Conservation of African-Eurasian Migratory Birds
}

these areas of overlap - particularly on the species criterion (IPA criterion A and the Key Biodiversity Area vulnerability criterion). The IPA criteria $\mathrm{B}$ and $\mathrm{C}$ could be used for application of the biomes criterion for KBAs, but this criterion has not yet been widely used in the KBA context, therefore we did not further analyze the five IPAs which met these criteria alone.

In Macedonia, the national site selection strategy focused initially on selecting larger sites, as these, on average, contain a high number of qualifying species and a complex of habitat types. The distribution and shape of protected areas (PAs) was also considered and where possible, the IPA boundaries were delineated based on the PA boundary.

The KBA vulnerability criterion is not applicable to plants in this study as the four red listed species from Macedonia previously considered threatened at global level using pre-2001 IUCN criteria (Walter \& Gillett 1998) have not been reassessed using current criteria and therefore do not appear on the current IUCN Global Red List (IUCN 2010). However, these and 73 other species (of the 102 species used as trigger species in the frame of IPA criteria) match the KBA irreplaceability criterion and so were used as trigger species for selecting KBAs. Of these, 57 species possess a restricted range which is here defined as less than $5,000 \mathrm{~km}^{2}$, (KBA subcriterion a), and 20 species have a clumped distribution (sub-criterion b) present only at a few localities over a large range ${ }^{2}$. Out of these 57 restricted-range species, 36 species, with very limited distributions (here defined as less than $500 \mathrm{~km}^{2}$ ) were also considered separately as we believe that, when assessed by the red listing process, they are likely to qualify as globally threatened, in which case they could be used as trigger species under the vulnerability criterion. The other 21 restricted-range species occupy larger ranges but all are less than $5,000 \mathrm{~km}^{2}$. However, according to the KBA methodology the definition of "restricted range" is set to $50,000 \mathrm{~km}^{2}$ (Langhammer et al. 2007). We consider that the latter is more suitable for large animals than for plants, and so preferred to use a smaller threshold of $5,000 \mathrm{~km}^{2}$. Five of the IPA sites were excluded (comprising two sites which did not qualify under the vulnerability criterion, as they had been identified as

\footnotetext{
${ }^{2}$ Langhammer et al. (2007) refer to 'clumped distributions', which we interpret as those species with a large range but only known from a few localities within that range. The populations are widely scattered within that range.
} 
IPAs using criterion $\mathrm{C}$ (threatened habitats), and three sites because they were designated as IPAs on the basis of European threat status - criterion Aii: Bern Convention and Habitat Directive lists).

Fungi, though not plants, are considered alongside plants within the IPA analysis. The above situation applies to fungal species i.e. they are threatened on a European level but they have not been globally assessed using IUCN criteria. There are no known restricted range fungal species in Macedonia, so fungi were omitted from these KBA analyses .

\section{IBAs}

Identification of IBAs started in 2007 and, by 2011 24 IBAs had been identified (Velevski et al. 2010). Twenty two of them have been confirmed by BirdLife International, and two more are in the proposal stage. All IBAs were checked against KBA criteria, resulting in the selection of 15 sites that meet the thresholds set by Langhammer et al. (2007) for identification of KBAs. These include 11 sites holding Endangered (EN) species (the Egyptian Vulture Neophron percnopterus), one site of importance for the Egyptian Vulture and the Vulnerable Eastern Imperial Eagle Aquila heliaca, two for the Vulnerable Dalmatian Pelican Pelecanus crispus, and one site meeting the irreplaceability criterion for Lesser Kestrel Falco naumanni ( $>1 \%$ of global population in the breeding period).

Of those IBAs that do not meet the KBA criteria, three were identified under IBA criterion A1. At one of these sites, the trigger species is Near-threatened and such species are not used for identification of KBAs, and in the other two the population of the trigger species concerned (Eastern Imperial Eagle) does not exceed the threshold of 10 pairs set in Langhammer et al. (2007). Three further excluded IBAs meet the IBA criterion A3 (assemblages characteristic of the Eurasian Highmontane biome), but the population sizes of the trigger species have not been estimated, so we have excluded them as KBAs. At the remaining IBA of global importance, Lake Ohrid, none of the species triggers IBA criterion A4i ( $1 \%$ of the global population), while A4iii is not used for KBA identification. The two remaining proposed IBAs are of European importance only (IBA criterion B2).

\section{Delineation of KBAs}

All qualifying individual IPAs and IBAs automatically became KBAs with the same boundary

- KBAs that result from overlapping IPAs and IBAs were delineated on the bases of the union of their surfaces

- In more complex cases (two or three KBAs had to be delineated from several overlapping IPAs and/or IBAs) the boundaries of either IPAs or IBAs were used to delineate KBAs.

\section{RESULTS}

The KBA identification methodology was applied to 42 IPAs $\left(6,496 \mathrm{~km}^{2}\right.$ total surface area) and 24 IBAs $\left(6,907 \mathrm{~km}^{2}\right.$ total surface area, Fig. 2), from which 42 KBAs have been identified for Macedonia -28 for plants only, six for birds only and eight for both plants and birds (Appendix 1). Of these eight KBAs triggered for both plants and birds: one (Babuna, Topolka and lower Bregalnica) combines three IPAs with one IBA into a single KBA; a second (Tikvesh-Raec) combines one IPA with two IBAs; and the remaining six sites each combine a single IPA with a single IBA. Five IPAs and nine IBAs did not meet KBAs criteria.

Those IPAs and IBAs that meet KBA criteria overlap by $1,302 \mathrm{~km}^{2}$ ( $5 \%$ of the country territory), or $19 \%$ of all IPAs or $20 \%$ of all IBAs. The combined surface area of the $42 \mathrm{KBAs}$ delineated based on IPAs and IBAs is $9,671 \mathrm{~km}^{2}$ ( $38 \%$ of the area of the country).

The size of the identified KBAs (Appendix 1, Fig. 3) ranges from $8.72 \mathrm{~km}^{2}$ to $1131.64 \mathrm{~km}^{2}$ (KBAMonospitovo and KBA Pelagonia respectively).

The numbers of species of birds and plants that trigger the KBA criteria and sub-criteria is shown in Table 1, while the summary of the numbers of KBAs triggered by each of the criteria and sub-criteria for birds and plants is given in Table 2 .

A more detailed analysis of the relationships between trigger species and KBAs is given in Table 3. It can be seen that most sites contain more than one trigger species while one particular site holds as many as 15 trigger species (Table 3 and Appendix 1).

Out of the 81 species used to trigger KBAs, 36 plant species are found in only one site exclusively and two bird species meet the criteria at only one site each, resulting with 38 sites triggered by one species only. Each of 20 other species can be found in two sites only (Table 3), clearly showing the high endemism among 


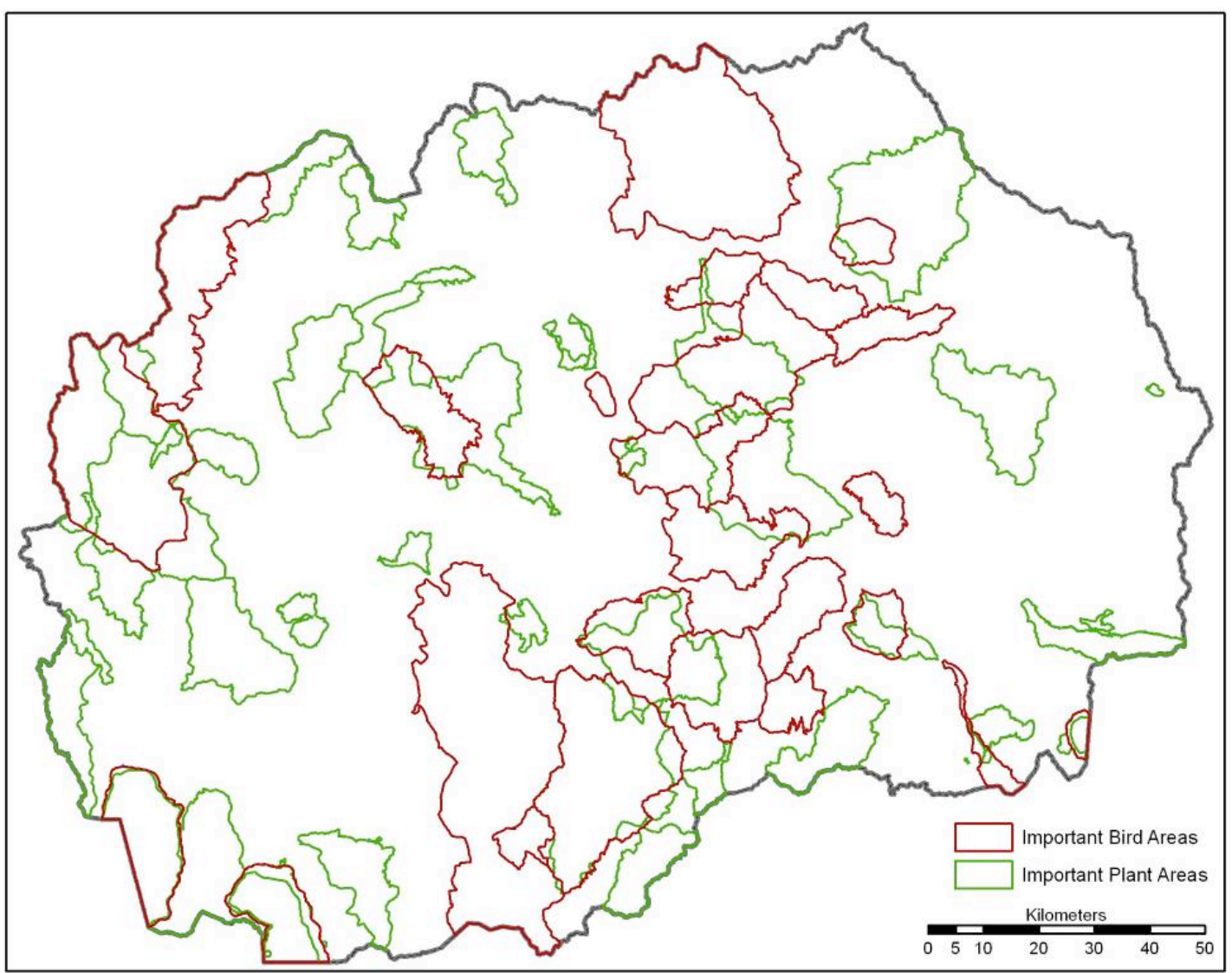

Figure 2. Important Bird Areas and Important Plant Areas in Macedonia

Table 1. Summary of the numbers of species of birds and plants triggering each of the KBA criteria and subcriteria

\begin{tabular}{|l|c|c|c|c|c|c|c|c|}
\hline \multirow{2}{*}{$\begin{array}{l}\text { Higher } \\
\text { taxon }\end{array}$} & \multicolumn{2}{|c|}{$\begin{array}{c}\text { Vulnerability } \\
\text { criterion }\end{array}$} & \multicolumn{5}{|c|}{ Irreplaceability criterion } & Total \\
\hline CR & EN & VU & $\begin{array}{c}\text { Highly restricted- } \\
\text { range species } \\
\text { (distribution }<500 \mathbf{~ k m}^{2} \text { ) }\end{array}$ & $\begin{array}{c}\text { Restricted-range } \\
\text { species (distribution } \\
\left.<5,000 \mathbf{k m}^{2}\right)\end{array}$ & $\begin{array}{c}\text { Species with large } \\
\text { ranges but clump- } \\
\text { ed populations }\end{array}$ & $\begin{array}{c}\text { Globally } \\
\text { significant } \\
\text { congregations }\end{array}$ & \\
\hline Birds & & 1 & 2 & & & & 1 & 4 \\
\hline Plants & & & & 36 & 21 & 20 & & 77 \\
\hline Total & & 1 & 2 & 36 & 21 & 20 & 1 & 81 \\
\hline
\end{tabular}

the plants.

Fifteen KBAs harbour narrowly endemic species (Appendix 1), which after official assessment are expected to be given some of the unfavorable conservation categories (VU, EN or CR), and some in the future might qualify as Alliance for Zero Extinction sites.

Analysis of the relationship of KBAs with the protected area network in Macedonia (total coverage of all protected area is $2,248 \mathrm{~km}^{2}$ or $8.7 \%$ of the country's territory, these figures are more precise than those given earlier by Melovski et al. 2011) was performed in order to assess their conservation status. This showed that $73 \%$ of the total area of IPAs and $65 \%$ of IBAs overlap with national protected areas; in total, $81 \%$ of the area of KBAs overlap with protected areas. However, only $25 \%$ of the protected area network overlaps with IPAs and only $21 \%$ with IBAs; overall, only $19 \%$ of the area of Macedonia's PAs overlaps with KBAs (Fig. 3).

The proposed representative national protected area network (5206.4 $\mathrm{km}^{2}$, Melovski et al. 2011), includes $4174.4 \mathrm{~km}^{2}$ of the identified KBAs (43\%), conversely, $80 \%$ of the proposed representative protected area network is covered by KBAs. 


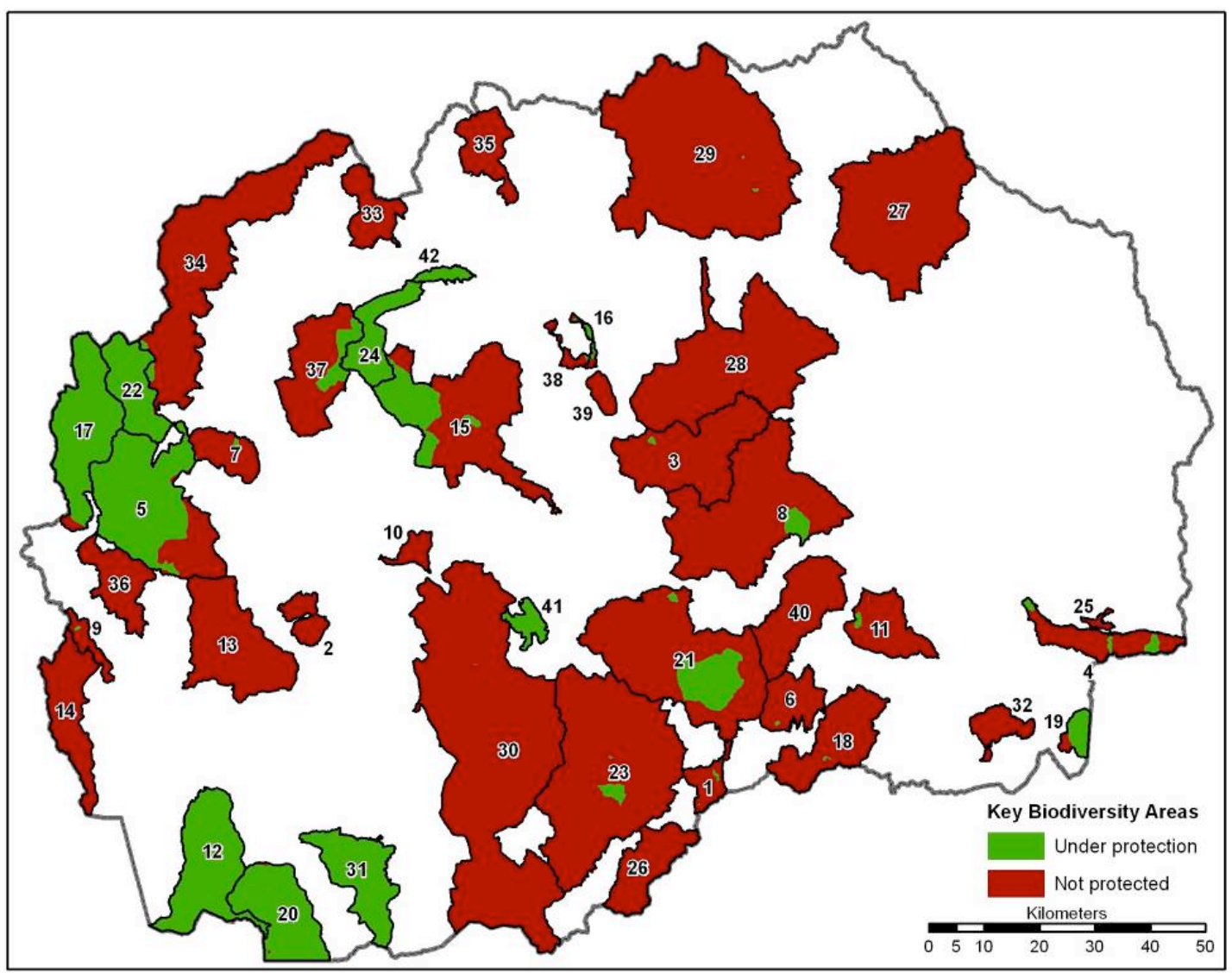

Figure 3. Key Biodiversity Areas in Macedonia, as identified from the Important Plant Areas and Important Bird Areas.

Table 2. Summary of the numbers of KBAs triggered by each of the criteria/subcriteria for each higher taxonomic group

\begin{tabular}{|c|c|c|c|c|c|c|c|}
\hline \multirow{2}{*}{$\begin{array}{l}\text { Higher } \\
\text { taxon }\end{array}$} & \multicolumn{3}{|c|}{$\begin{array}{l}\text { Vulnerability } \\
\text { criterion }\end{array}$} & \multicolumn{4}{|c|}{ Irreplaceability criterion } \\
\hline & CR & EN & vu & $\begin{array}{c}\text { Highly restricted- range } \\
\text { species (distribution } \\
\left.<500 \mathrm{~km}^{2}\right)\end{array}$ & $\begin{array}{c}\text { Restricted-range } \\
\text { species (distribution } \\
<5,000 \mathrm{~km}^{2} \text { ) }\end{array}$ & $\begin{array}{l}\text { Species with large } \\
\text { ranges but clumped } \\
\text { populations }\end{array}$ & $\begin{array}{c}\text { Globally } \\
\text { significant } \\
\text { congregations }\end{array}$ \\
\hline Birds & & 12 & 3 & & & & 1 \\
\hline Plants & & & & 19 & 33 & 9 & \\
\hline $\begin{array}{l}\text { Total number } \\
\text { of sites }\end{array}$ & & 12 & 3 & 19 & 33 & 9 & 1 \\
\hline
\end{tabular}

\section{DISCUSSION}

Identification of KBAs in the Republic of Macedonia on the basis of existing, recognized, globally important areas for biodiversity (in this case IBAs and IPAs) was meant to compensate for the lack of distribution range data for different taxonomic groups, lack of population data for the most of the species and lack of national red lists. However, it was not possible to automatically designate IPAs and IBAs as KBAs due to the stricter criteria for identification of KBAs.

Additionally, initial implementation of IPA criteria in Macedonia was very challenging. The main obstacle to full implementation of the IPA methodology in Macedonia was lack of sufficient data, or the existence of only old data on plants and fungi, lack of assessment of the threat status of the flora at global level and the absence of a national Red List (Radford \& Odé 2009; Melovski et al. 2010). The IUCN Global Red List is currently an inadequate indicator of the levels of globally threatened plant species in Macedonia (and elsewhere in the Balkans). IPA methodology recognizes this and compensates by considering regionally threatened species (on European conventions, IPA criterion Aii,), 
Table 3. Summary of frequency distributions of the number of trigger species ( $n$ ) per KBA, and the number of KBAs per trigger species

\begin{tabular}{|c|c|c|}
\hline & $\begin{array}{c}\text { No. of KBAs holding } \\
\mathbf{n} \text { trigger species }\end{array}$ & $\begin{array}{c}\text { No. of trigger species } \\
\text { occurring in } \mathbf{n} \text { KBAs }\end{array}$ \\
\hline 1 & 11 & 38 \\
\hline 2 & 12 & 20 \\
\hline 3 & 2 & 9 \\
\hline 4 & 2 & 3 \\
\hline 5 & 1 & 5 \\
\hline 6 & 3 & 3 \\
\hline 7 & 5 & 0 \\
\hline 8 & 2 & 0 \\
\hline 9 & 1 & 1 \\
\hline 10 & 0 & 0 \\
\hline 11 & 3 & 1 \\
\hline 12 & 1 & 1 \\
\hline 15 & 1 & 0 \\
\hline
\end{tabular}

threatened national and sub-regional endemics and species richness and habitats; all of which are irrelevant for KBA identification. The KBA methodology has not yet been applied in ways that harness such alternative measures so there is a potential for IPAs to be omitted from KBAs list (in Macedonia this applies at five sites: Negorci Spa, Ohrid Lake, Pehchevo-Judovi Livadi, Plachkovica and Prespa Lake). Practically IPA methodology compensates for the incompleteness of IUCN Red List as well as the present lack of IUCN Global Red List data for plants. It is therefore not possible to apply "vulnerability" criterion in case of Macedonia. The KBA methodology by-passes this by the introduction of the "irreplaceability" criterion with several sub-criteria (Langhammer et al. 2007). In Macedonia the "restricted range species" subcriterion (sub-criterion a) was the most appropriate due to limited knowledge on the exact distribution of many plant species. It corresponds to IPA criterion Aiii (threatened narrow endemics) and to a certain extent to IPA criterion Aiv (threatened near endemics). Most of the IPA qualifying species fall into this KBA criterion (Appendix 1). Very few Aiii plant species and some Aiv species fall into sub-criterion (b) (species with large but clumped distributions). More knowledge is needed to better assess many other IPA species and other plant species which were not included in the original IPA list.

As an example, only five IPAs in Macedonia have been identified for globally threatened species using IPA criterion Ai, which draws on the 1997 IUCN Red List (Walter \& Gillett 1998). They were also identified as KBAs because these species were restricted-range species in the same time, but they do not have the same KBA status since the four Ai species do not appear in the current IUCN Red List (IUCN 2010). (These species are Astragalus physocalyx Fisch., Ranunculus degenii Kummerle \& Jav, Ranunculus cacuminis Strid \& Papan and Thymus oehmianus Ronninger \& Soška). This is important because it may lead to underestimation of priority level if KBAs are subsequently further prioritized using the level of threat to the trigger species, for example to prioritize conservation action or investment. This has happened in some of the prioritization exercises during the development of the CEPF Mediterranean Ecosystem Profile (CEPF 2011). Many endemic and near-endemic species in Macedonia have yet to be properly assessed and the flora may prove to be more threatened than current lists suggest (Table 2 and Appendix 1).

Ideally, comprehensive IUCN species assessments should be undertaken but this will require considerable time, capacity and resources, and in the meantime we recommend the use of an additional sub-criterion (a "highly restricted-range species") under the "irreplaceabillity" criterion, sub-criterion (a). This does not refer to any of the IUCN threat categories (Vulnerable, Endangered or Critically Endangered), but captures species with extremely limited distributions (such as the 36 Macedonian species with a range of less than $500 \mathrm{~km}^{2}$ in Table 2). This would begin to address the limitations in KBA identification resulting from lack of data on threat status for plants.

On the other hand, the $50,000 \mathrm{~km}^{2}$ threshold of distribution range for "restricted-range species" as proposed in KBA methodology (Langhammer et al. 2007) is too large for plants, although a well established threshold among ornithologists and mammologists (e.g. Stattersfield et al. 1998). A large proportion of Macedonian plant species (and indeed those of the Balkan Peninsula as a whole) have smaller ranges than this and would consequently fall within with the "irreplaceabillity - restricted range species" criterion. However, most of these species are not considered threatened, even if properly assessed. Thus, we suggest that $5,000 \mathrm{~km}^{2}$ is used instead, as the threshold to define "restricted-range species" for plants generally. In this 
way it is possible to overcome, at least in part, the lack of national Red Lists for plants and so to include in the KBAs system the majority of species that are most likely to be threatened due to their very limited distributions, among other reasons.

"Irreplaceability sub-criterion (b) was used only for species for which we have data about their range in neighbouring countries. It can however be assumed that some other species will meet this criterion. It is particularly difficult to implement the KBA threshold for this criterion; $5 \%$ of the global population at the site. In applying the irreplaceability criterion we mostly used the IPA threshold that is used in cases where comprehensive population data is unavailable i.e. that the site is 'one of the five best known sites' for the species.

Finally, we were not able to use "irreplaceability" sub-criterion (e) (bio-regionally restricted assemblages) due to the lack of sufficiently precise data. Thus, for the time being it is not possible to compensate for the lack of a criterion in the KBA methodology that reflects IPA criterion B (species richness) and especially criterion C (threatened habitats).

Although criteria for designation of IBAs with global significance and KBAs are compatible, seven globally important IBAs were excluded from KBA list in Macedonia. However, three of these sites (Shar Planina, river Radika catchment and Jakupica, all qualifying under $\mathrm{A} 3$ criterion) were covered by Macedonian KBAs network to a significant proportion due to their overlap with qualifying IPAs. The fourth one (Preod - Gjugjance) was covered only to a small extent. Similarly, one of the excluded IPA sites (Lake Prespa) is still part of the proposed KBAs network since it entirely overlaps with respective IBA of global importance. Lake Ohrid is a unique case; although identified as IPA of global importance (based on criterion C) and IBA of global importance (criteria A4i, A4iii and A4iv), this approach (combination of IPAs and IBAs only) failed to include this site of remarkable endemism in the KBA network.

In conclusion, the identification of KBAs by using IPAs and IBAs is a good tool to identify the most important sites for biodiversity in Macedonia and probably elsewhere. There are however, some exceptions (e.g. Lake Ohrid). In order to overcome this, one should take some freshwater taxonomic groups into analyses (in Macedonia fishes are the most appropriate since there are considerable data available for this group).

The analysis of the protection status of the proposed KBAs in Macedonia shows that extensive areas harboring important and threatened biodiversity components are not currently protected. Only 19\% of current protected areas surface overlaps with KBAs. This means that the national protected area system does not adequately cover the country's most important biodiversity and neither is it comprehensive.

The oldest and largest protected areas in Macedonia were designated mainly on the basis of their forest cover, beautiful appearance and the presence of game species. Most of the recently designated protected areas are very small and unevenly distributed throughout the country. They do not cover the whole range of important habitats as well. The PA system in Macedonia is currently under revision, in compliance with the Law on Nature Protection of 2004, a project supported by GEF and implemented by UNDP. If the proposed revisions to the protected area network are implemented (Melovski et al. 2011) the situation will be much improved with $80 \%$ of the proposed network covered by KBAs, including $43 \%$ of the surface of KBAs identified during this study.

Since KBAs (and IPAs and IBAs individually) follow strict and rigorous criteria for the identification as internationally important sites, they should be used to contribute to the building of a more comprehensive PA system in Macedonia, in addition to increasing the country's compliance with international targets for biodiversity approved by the Convention on Biological Diversity.

\section{REFERENCES}

Albrecht, C.\& T. Wilke (2008). Ancient Lake Ohrid: biodiversity and evolution. Hydrobiologia 615:103-140.

Anderson, S. (2002). Identifying Important Plant Areas. Plantlife International. Salisbury, UK.

CEPF (2011). Bassin Mediterraneen : profil d'écosystème. Downloadable at http://www.cepf.net/Documents/ Mediterranean_Summary_Booklet_Francais.pdf. Download on 15 September 2011.

IUCN (2010). IUCN Red List of Threatened Species. Version 2010.4. <www.iucnredlist.org>. Downloaded on 01 March 2011.

Kuzmanov, B. (Ed.) (1979). Flora Reipublicae Popularis Bulgaricae - Vol. VII. Academiae Scientarum Bulgaricae, 
Appendix 1. Data for trigger species occurring at each KBA in Macedonia

\begin{tabular}{|c|c|c|c|c|c|c|}
\hline No. & $\begin{array}{l}\text { KBAs } \\
\text { ( }{ }^{*} \text { sites holding narrow } \\
\text { endemic species) }\end{array}$ & $\begin{array}{l}\text { Bird species } \\
\text { that trigger } \\
\text { the Vulnera- } \\
\text { bility criterion }\end{array}$ & $\begin{array}{l}\text { Bird species } \\
\text { that trigger the } \\
\text { Irreplaceabillity } \\
\text { criterion (d - } \\
\text { maintaining } \\
1 \% \text { of } \\
\text { global } \\
\text { population) }\end{array}$ & $\begin{array}{l}\text { Plant species } \\
\text { that trigger the } \\
\text { Irreplaceabillity } \\
\text { criterion - Highly } \\
\text { restricted-range } \\
\text { species (range }<500 \\
\mathbf{k m}^{2} \text { ) }\end{array}$ & $\begin{array}{l}\text { Plant species } \\
\text { that trigger the } \\
\text { Irreplaceabillity } \\
\text { criterion - Restri- } \\
\text { cted range species } \\
\text { (range }<5,000 \mathrm{~km}^{2} \text { ) } \\
\text { (Threshold }-5 \% \text { of } \\
\text { the global popula- } \\
\text { tion or one of the } 5 \\
\text { best sites in MK) }\end{array}$ & $\begin{array}{l}\text { Plant species that trigger } \\
\text { the Irreplaceabillity } \\
\text { criterion - Species } \\
\text { with large but clumped } \\
\text { populations } \\
\text { (Threshold }-5 \% \text { of the } \\
\text { global population or one } \\
\text { of the } 5 \text { best sites in MK) }\end{array}$ \\
\hline 1 & $\begin{array}{l}\text { KBA Alshar* (4585 ha) } \\
=\text { IPA Alshar }\end{array}$ & & & $\begin{array}{l}\text { Centaurea leucomalla } \\
\text { Bornm. } \\
\text { Knautia caroli- } \\
\text { rechingeri Micev. } \\
\text { Thymus alsarensis } \\
\text { Ronn. } \\
\text { Viola arsenica Beck } \\
\text { Viola allchariensis } \\
\text { Beck } \\
\text { Onobrychis degenii } \\
\text { Dörfl. }\end{array}$ & $\begin{array}{l}\text { Alkanna pulmonaria } \\
\text { Griseb. }\end{array}$ & Eryngium serbicum Pancic \\
\hline 2 & $\begin{array}{l}\text { KBA Baba Sach-Luben } \\
\text { (4875 ha) } \\
=\text { IPA Baba Sach-Luben }\end{array}$ & & & & & $\begin{array}{l}\text { Erodium guicciardii Heldr. } \\
\text { ex Boiss. } \\
\text { Centaurea grbavacensis } \\
\text { (Rohl.) Stoy. \& Acht. }\end{array}$ \\
\hline 3 & $\begin{array}{l}\text { KBA Babuna - Topolka - } \\
\text { lower Bregalnica* }(28812 \\
\text { ha) } \\
\text { = IPA Babuna River gorge, } \\
\text { IPA Topolka River gorge and } \\
\text { IPA Krivolak* which overlap } \\
\text { with IBA River Topolka-river } \\
\text { Babuna-river Bregalnica }\end{array}$ & $\begin{array}{l}\text { Neophron } \\
\text { percnopterus } \\
\text { (4-5 pairs) } \\
\text { (EN) }\end{array}$ & & $\begin{array}{l}\text { Astragalus cernjavskii } \\
\text { Stoj. } \\
\text { Hedysarum } \\
\text { macedonicum Bornm. } \\
\text { Salvia jurisicii Kosanin } \\
\text { Tulipa marianae Lindtn. }\end{array}$ & $\begin{array}{l}\text { Silene paeoniensis } \\
\text { Bornm. } \\
\text { Silene viscariopsis } \\
\text { Bornm. } \\
\text { Anchusa } \\
\text { macedonica Degen } \\
\text { \& Dorfl. } \\
\text { Galium rhodopeum } \\
\text { Velen. }\end{array}$ & $\begin{array}{l} \\
\text { Alkanna noneiformis } \\
\text { Griseb. } \\
\text { Alkanna stribrnyi Velen. }\end{array}$ \\
\hline 4 & $\begin{array}{l}\text { KBA Belasica* (11181 ha) } \\
=\text { IPA Belasica }\end{array}$ & & & $\begin{array}{l}\text { Viola stojanowii } \\
\text { W.Becker }\end{array}$ & $\begin{array}{l}\text { Hypericum dimoniei } \\
\text { Vel. (considered } \\
\text { now variety of } \mathrm{H} \text {. } \\
\text { Olympicum) }\end{array}$ & \\
\hline 5 & $\begin{array}{l}\text { KBA Bistra (42164 ha) } \\
=\text { IPA Bistra }\end{array}$ & & & & $\begin{array}{l} \\
\text { Colchicum } \\
\text { pieperanum Markgr. } \\
\text { Sempervivum } \\
\text { kosaninii Praeger }\end{array}$ & $\begin{array}{l}\text { Trifolium pilczii Adam. } \\
\text { Alkanna noneiformis } \\
\text { Griseb. } \\
\text { Oxytropis purpurea } \\
\text { (Baldacci) Markgraf } \\
\text { Cynoglossum scardicum } \\
\text { (Bornm.) Greuter \& Burdet }\end{array}$ \\
\hline 6 & $\begin{array}{l}\text { KBA Bošavija (9283 ha) } \\
=\text { IBA Bošavija }\end{array}$ & $\begin{array}{l}\text { Neophron } \\
\text { percnopterus } \\
\text { (1-3 pairs) (EN) }\end{array}$ & & & & \\
\hline 7 & $\begin{array}{l}\text { KBA Bukovic-Straza (7766 } \\
\text { ha) } \\
=\text { IPA Bukovic-Straza }\end{array}$ & & & & & $\begin{array}{l}\text { Erodium guicciardii Heldr. } \\
\text { ex Boiss. } \\
\text { Centaurea grbavacensis } \\
\text { (Rohl.) Stoy. \& Acht. } \\
\text { Cynoglossum scardicum } \\
\text { (Bornm.) Greuter \& Burdet }\end{array}$ \\
\hline 8 & $\begin{array}{l}\text { KBA Central Vardar (50251 } \\
\text { ha) } \\
=\text { IBA Gradsko-Rosoman- } \\
\text { Negotino (overlaps with IPA } \\
\text { Krivolak) }\end{array}$ & $\begin{array}{l}\text { Neophron } \\
\text { percnopterus } \\
(6 \text { ind.) (EN) }\end{array}$ & & $\begin{array}{l}\text { Astragalus cernjavskii } \\
\text { Stoj. } \\
\text { Hedysarum } \\
\text { macedonicum Bornm. } \\
\text { Salvia jurisicii Kosanin } \\
\text { Tulipa marianae Lindtn. }\end{array}$ & $\begin{array}{l}\text { Anchusa } \\
\text { macedonica Degen } \\
\text { \& Dorfl. } \\
\text { Galium rhodopeum } \\
\text { Velen. }\end{array}$ & \\
\hline 9 & $\begin{array}{l}\text { KBA Crn Drim Gorge* (3212 } \\
\text { ha) } \\
=\text { IPA Crn Drim Gorge }\end{array}$ & & & $\begin{array}{l}\text { Campanula debarensis } \\
\text { Rech. f. }\end{array}$ & & $\begin{array}{l}\text { Melampyrum } \\
\text { heracleoticum Boiss. \& } \\
\text { Orph. }\end{array}$ \\
\hline 10 & $\begin{array}{l}\text { KBA Dautica-Barbaras } \\
\text { (3195 ha) } \\
\text { = IPA Makedonski Brod- } \\
\text { Barbaras }\end{array}$ & & & $\begin{array}{l}\text { Dianthus kapinensis } \\
\text { Markg. et Lindtn. }\end{array}$ & & $\begin{array}{l}\text { Centaurea grbavacensis } \\
\text { (Rohl.) Stoy. \& Acht. }\end{array}$ \\
\hline
\end{tabular}




\begin{tabular}{|c|c|c|c|c|c|c|}
\hline No. & $\begin{array}{l}\text { KBAs } \\
\text { (* sites holding narrow } \\
\text { endemic species) }\end{array}$ & $\begin{array}{l}\text { Bird species } \\
\text { that trigger } \\
\text { the Vulnera- } \\
\text { bility criterion }\end{array}$ & $\begin{array}{l}\text { Bird species } \\
\text { that trigger the } \\
\text { Irreplaceabillity } \\
\text { criterion (d - } \\
\text { maintaining } \\
1 \% \text { of } \\
\text { global } \\
\text { population) }\end{array}$ & $\begin{array}{l}\text { Plant species } \\
\text { that trigger the } \\
\text { Irreplaceabillity } \\
\text { criterion - Highly } \\
\text { restricted-range } \\
\text { species (range }<500 \\
\mathrm{~km}^{2} \text { ) }\end{array}$ & $\begin{array}{l}\text { Plant species } \\
\text { that trigger the } \\
\text { Irreplaceabillity } \\
\text { criterion - Restri- } \\
\text { cted range species } \\
\text { (range }<5,000 \mathrm{~km}^{2} \text { ) } \\
\text { (Threshold - } 5 \% \text { of } \\
\text { the global popula- } \\
\text { tion or one of the } 5 \\
\text { best sites in MK) }\end{array}$ & $\begin{array}{l}\text { Plant species that trigger } \\
\text { the Irreplaceabillity } \\
\text { criterion - Species } \\
\text { with large but clumped } \\
\text { populations } \\
\text { (Threshold - } 5 \% \text { of the } \\
\text { global population or one } \\
\text { of the } 5 \text { best sites in MK) }\end{array}$ \\
\hline 11 & $\begin{array}{l}\text { KBA Demir Kapija* (11992 } \\
\text { ha) } \\
=\text { IPA Demir Kapija which } \\
\text { overlaps with the same IBA }\end{array}$ & $\begin{array}{l}\text { Neophron } \\
\text { percnopterus } \\
\text { (2-3 pairs) (EN) }\end{array}$ & & $\begin{array}{l}\text { Heptaptera } \\
\text { macedonica (Bornm.) } \\
\text { Tutin }\end{array}$ & $\begin{array}{l}\text { Anthemis meteorica } \\
\text { Hausskn. } \\
\text { Verbascum } \\
\text { macedonicum } \\
\text { Košanin \& Murb. }\end{array}$ & \\
\hline 12 & $\begin{array}{l}\text { KBA Galichica* (24876 ha) } \\
=\text { IPA Galichica }\end{array}$ & & & $\begin{array}{l}\text { Centaurea soskae } \\
\text { Hayek ex Košanin } \\
\text { Jurinea taygetea } \\
\text { Halácsy (erroneous } \\
\text { - this recently proved } \\
\text { to be other species - } \\
\text { endemic) } \\
\text { Nepeta ernesti-mayeri } \\
\text { Dikl. et Nikolic }\end{array}$ & $\begin{array}{l} \\
\text { Ajuga piskoi Degen } \\
\text { \& Bald. }\end{array}$ & $\begin{array}{l}\text { Erodium guicciardii Heldr. } \\
\text { ex Boiss. } \\
\text { Trifolium pilczii Adam. } \\
\text { Eryngium serbicum Pancic } \\
\text { Alkanna noneiformis } \\
\text { Griseb. } \\
\text { Oxytropis purpurea } \\
\text { (Baldacci) Markgraf } \\
\text { Cynoglossum scardicum } \\
\text { (Bornm.) Greuter \& Burdet } \\
\text { Melampyrum } \\
\text { heracleoticum Boiss. \& } \\
\text { Orph. } \\
\text { Anchusa serpentinicola } \\
\text { Rech.f. } \\
\text { Viola eximia Form. } \\
\text { Astragalus baldaccii } \\
\text { Degen } \\
\text { Rindera graeca (A.DC.) } \\
\text { Boiss. \& Heldr. }\end{array}$ \\
\hline 13 & $\begin{array}{l}\text { KBA llinska Planina }(27526 \\
\text { ha) = IPA Ilinska Planina Mt. }\end{array}$ & & & & & $\begin{array}{l}\text { Oxytropis purpurea } \\
\text { (Baldacci) Markgraf }\end{array}$ \\
\hline 14 & $\begin{array}{l}\text { KBA Jablanica (16201 ha) } \\
=\text { IPA Jablanica }\end{array}$ & & & & $\begin{array}{l}\text { Fritillaria } \\
\text { macedonica Bornm. }\end{array}$ & $\begin{array}{l}\text { Trifolium pilczii Adam. } \\
\text { Cynoglossum scardicum } \\
\text { (Bornm.) Greuter \& Burdet } \\
\text { Narthecium scardicum } \\
\text { Košanin } \\
\text { Soldanella pindicola } \\
\text { Hausskn. } \\
\text { Viola eximia Form. } \\
\text { Minuartia baldaccii } \\
\text { (Halácsy) Mattf. }\end{array}$ \\
\hline 15 & $\begin{array}{l}\text { KBA Jakupica* (42099) } \\
\text { = IPA Jakupica (also } \\
\text { overlaps with IBA Jakupica, } \\
\text { which does not qualify as } \\
\text { KBA) }\end{array}$ & & & $\begin{array}{l}\text { Colchicum } \\
\text { macedonicum Košanin } \\
\text { Pedicularis ferdinandi } \\
\text { Bornm. } \\
\text { Sempervivum } \\
\text { macedonicum Prager } \\
\text { Moehringia minutiflora } \\
\text { Bornm } \\
\text { Saxifraga } \\
\text { karadzicensis (Deg. et } \\
\text { Koš.) Bornm. }\end{array}$ & $\begin{array}{l}\text { } \\
\\
\text { Genista nissana } \\
\text { Petrovic } \\
\text { Pedicularis } \\
\text { limnogena A. Kerner }\end{array}$ & $\begin{array}{l}\text { Centaurea grbavacensis } \\
\text { (Rohl.) Stoy. \& Acht. } \\
\text { Alkanna noneiformis } \\
\text { Griseb. } \\
\text { Melampyrum } \\
\text { heracleoticum Boiss. \& } \\
\text { Orph. } \\
\text { Narthecium scardicum } \\
\text { Košanin } \\
\text { Soldanella pindicola } \\
\text { Hausskn. }\end{array}$ \\
\hline 16 & $\begin{array}{l}\text { KBA Katlanovo - Badar } \\
\text { (1076 ha) } \\
=\text { IPA Katlanovo-Bader }\end{array}$ & & & & $\begin{array}{l}\text { Anchusa } \\
\text { macedonica Degen } \\
\text { \& Dorfl. }\end{array}$ & Alkanna stribrnyi Velen. \\
\hline 17 & $\begin{array}{l}\text { KBA Korab-Deshat* ( } 25857 \\
\text { ha) } \\
\text { = IPA Korab-Deshat (also } \\
\text { overlaps with IBA Radika } \\
\text { River catchment, which } \\
\text { does not qualify as KBA) }\end{array}$ & & & $\begin{array}{l}\text { Ranunculus wettsteinii } \\
\text { Dörfl. } \\
\text { Silene schmuckeri } \\
\text { Boiss. }\end{array}$ & $\begin{array}{l}\text { Ranunculus degenii } \\
\text { Kummerle \& Jav. } \\
\text { Fritillaria } \\
\text { macedonica Bornm. } \\
\text { Sempervivum } \\
\text { kosaninii Praeger }\end{array}$ & $\begin{array}{l}\text { Narthecium scardicum } \\
\text { Košanin } \\
\text { Soldanella pindicola } \\
\text { Hausskn. }\end{array}$ \\
\hline 18 & $\begin{array}{l}\text { KBA Kozhuf (17991 ha) } \\
=\text { IPA Kozhuf-Dudica }\end{array}$ & & & & $\begin{array}{l}\text { Hypericum dimoniei } \\
\text { Vel. (considered } \\
\text { now variety of } H \text {. } \\
\text { olympicum) }\end{array}$ & Viola eximia Form. \\
\hline
\end{tabular}




\begin{tabular}{|c|c|c|c|c|c|c|}
\hline No. & $\begin{array}{l}\text { KBAs } \\
\text { (* sites holding narrow } \\
\text { endemic species) }\end{array}$ & $\begin{array}{l}\text { Bird species } \\
\text { that trigger } \\
\text { the Vulnera- } \\
\text { bility criterion }\end{array}$ & $\begin{array}{l}\text { Bird species } \\
\text { that trigger the } \\
\text { Irreplaceabillity } \\
\text { criterion (d - } \\
\text { maintaining } \\
1 \% \text { of } \\
\text { global } \\
\text { population) }\end{array}$ & $\begin{array}{l}\text { Plant species } \\
\text { that trigger the } \\
\text { Irreplaceabillity } \\
\text { criterion - Highly } \\
\text { restricted-range } \\
\text { species (range }<500 \\
\mathbf{k m}^{2} \text { ) }\end{array}$ & $\begin{array}{l}\text { Plant species } \\
\text { that trigger the } \\
\text { Irreplaceabillity } \\
\text { criterion - Restri- } \\
\text { cted range species } \\
\text { (range }<5,000 \mathrm{~km}^{2} \text { ) } \\
\text { (Threshold }-5 \% \text { of } \\
\text { the global popula- } \\
\text { tion or one of the } 5 \\
\text { best sites in MK) }\end{array}$ & $\begin{array}{l}\text { Plant species that trigger } \\
\text { the Irreplaceabillity } \\
\text { criterion - Species } \\
\text { with large but clumped } \\
\text { populations } \\
\text { (Threshold }-5 \% \text { of the } \\
\text { global population or one } \\
\text { of the } 5 \text { best sites in MK) }\end{array}$ \\
\hline 19 & $\begin{array}{l}\text { KBA Lake Dojran ( } 3301 \text { ha) } \\
=\text { IBA Lake Dojran which } \\
\text { mostly overlaps with the } \\
\text { same IPA }\end{array}$ & $\begin{array}{l}\text { Pelecanus } \\
\text { crispus ( } 300- \\
450 \text { ind.) (VU) }\end{array}$ & & & $\begin{array}{l}\text { Only terrestrial } \\
\text { species: } \\
\text { Anthemis meteorica } \\
\text { Hausskn. }\end{array}$ & $\begin{array}{l}\text { Centaurea kosaninii Hayek } \\
\text { Alkanna stribrnyi Velen. }\end{array}$ \\
\hline 20 & $\begin{array}{l}\text { KBA Lake Prespa (19755) } \\
=\text { IBA Prespa Lake } \\
\text { (also overlaps with IPA Lake } \\
\text { Prespa, which does not } \\
\text { qualify as KBA) }\end{array}$ & $\begin{array}{l}\text { Pelecanus } \\
\text { crispus (500- } \\
1000 \text { ind.) (VU) }\end{array}$ & & & & \\
\hline 21 & $\begin{array}{l}\text { KBA Lake Tikvesh-Raec } \\
\text { (52600 ha) } \\
=\text { IPA Raec gorge-Tikveš } \\
\text { Lake which overlaps with } \\
\text { IBA River Raec Valley and } \\
\text { IBA Tikvesh Lake }\end{array}$ & $\begin{array}{l}\text { Neophron } \\
\text { percnopterus } \\
(2-3 \text { pairs and } \\
3 \text { pairs })(E N)\end{array}$ & & $\begin{array}{l}\text { Heptaptera } \\
\text { macedonica (Bornm.) } \\
\text { Tutin } \\
\text { Verbascum herzogii } \\
\text { Borm. }\end{array}$ & $\begin{array}{l}\text { Alyssum doerfleri } \\
\text { Degen } \\
\text { Verbascum } \\
\text { macedonicum } \\
\text { Košanin \& Murb. }\end{array}$ & $\begin{array}{l}\text { Centaurea grbavacensis } \\
\text { (Rohl.) Stoy. \& Acht. } \\
\text { Alkanna stribrnyi Velen. }\end{array}$ \\
\hline 22 & $\begin{array}{l}\text { KBA Lukovo Pole - Kozha } \\
\text { (13242 ha) } \\
\text { = IPA Mavrovo (also } \\
\text { overlaps partially with IBA } \\
\text { Shar Planina, which does } \\
\text { not qualify as KBA) }\end{array}$ & & & & & $\begin{array}{l}\text { Eryngium serbicum Pancic } \\
\text { Alkanna noneiformis } \\
\text { Griseb. }\end{array}$ \\
\hline 23 & $\begin{array}{l}\text { KBA Mariovo ( } 65910 \text { ha) } \\
=\text { IPA Mariovo which } \\
\text { overlaps with IBA Mariovo }\end{array}$ & $\begin{array}{l}\text { Neophron } \\
\text { percnopterus } \\
\text { (4 pairs) (EN) }\end{array}$ & & $\begin{array}{l}\text { Asplenium } \\
\text { macedonicum Kümm. } \\
\text { Moehringia minutiflora } \\
\text { Bornm } \\
\text { Verbascum herzogii } \\
\text { Borm. }\end{array}$ & $\begin{array}{l}\text { Alyssum doerfleri } \\
\text { Degen } \\
\text { Stipa rechingeri } \\
\text { Martinovsky } \\
\text { Silene paeoniensis } \\
\text { Bornm. } \\
\text { Silene viscariopsis } \\
\text { Bornm. }\end{array}$ & $\begin{array}{l}\text { Centaurea grbavacensis } \\
\text { (Rohl.) Stoy. \& Acht. } \\
\text { Isoetes phrygia (Boiss.) } \\
\text { Hausskn. } \\
\text { Melampyrum } \\
\text { heracleoticum Boiss. \& } \\
\text { Orph. }\end{array}$ \\
\hline 24 & $\begin{array}{l}\text { KBA Matka - Kozjak* } \\
\text { (10618 ha) } \\
=\text { IPA Treska River Gorge } \\
\text { (no IBA proposed, although } \\
\text { holds endangered bird } \\
\text { species) }\end{array}$ & $\begin{array}{l}\text { Neophron } \\
\text { percnopterus } \\
\text { (1 pair) (EN) }\end{array}$ & & $\begin{array}{l}\text { Thymus oehmianus } \\
\text { Ronninger \& Soška } \\
\text { Dianthus kapinensis } \\
\text { Markg. et Lindtn. }\end{array}$ & $\begin{array}{l}\text { Genista nissana } \\
\text { Petrovic } \\
\text { Galium rhodopeum } \\
\text { Velen. }\end{array}$ & $\begin{array}{l}\text { Alkanna noneiformis } \\
\text { Griseb. } \\
\text { Melampyrum } \\
\text { heracleoticum Boiss. \& } \\
\text { Orph. }\end{array}$ \\
\hline 25 & $\begin{array}{l}\text { KBA Monospitovo ( } 872 \text { ha) } \\
=\text { IPA Strumica-Monospitovo }\end{array}$ & & & & & $\begin{array}{l}\text { Isoetes phrygia (Boiss.) } \\
\text { Hausskn. }\end{array}$ \\
\hline 26 & $\begin{array}{l}\text { KBA Nidze*(12897 ha) } \\
=\text { IPA Nidze }\end{array}$ & & & $\begin{array}{l}\text { Ranunculus cacuminis } \\
\text { Strid \& Papan } \\
\text { Viola brachphylla W. } \\
\text { Becker. }\end{array}$ & & $\begin{array}{l}\text { Sempervivum octopodes } \\
\text { Turill (half of the } \\
\text { population) } \\
\text { Centaurea grbavacensis } \\
\text { (Rohl.) Stoy. \& Acht. } \\
\text { Alkanna noneiformis } \\
\text { Griseb. } \\
\text { Viola eximia Form. }\end{array}$ \\
\hline 27 & $\begin{array}{l}\text { KBA Osogovo* (51849 ha) } \\
=\text { IPA Osogovo which } \\
\text { encompasses IBA } \\
\text { Osogovski Planini }\end{array}$ & $\begin{array}{l}\text { Neophron } \\
\text { percnopterus } \\
\text { (1 pair) (EN) }\end{array}$ & & $\begin{array}{l}\text { Genista fukarekiana } \\
\text { Micev. (local endemic - } \\
\text { not previously included } \\
\text { in A list) }\end{array}$ & & \\
\hline 28 & $\begin{array}{l}\text { KBA Ovche Pole (51622 ha) } \\
=\text { IPA Ovche Pole- } \\
\text { Bogoslovec which overlaps } \\
\text { with IBA Ovche Pole (and } \\
\text { partially to IBA Preod- } \\
\text { Gjugjance, that does not } \\
\text { meet KBA criteria) }\end{array}$ & $\begin{array}{l}\text { Neophron } \\
\text { percnopterus } \\
\text { (EN) (6 ind.) } \\
\text { Aquila heliaca } \\
\text { (12-15 pairs) } \\
\text { (VU) }\end{array}$ & & $\begin{array}{l}\text { Hedysarum } \\
\text { macedonicum Bornm. } \\
\text { Salvia jurisicii Kosanin }\end{array}$ & $\begin{array}{l}\text { Anchusa } \\
\text { macedonica Degen } \\
\text { \& Dorfl. } \\
\text { Galium rhodopeum } \\
\text { Velen. }\end{array}$ & \\
\hline
\end{tabular}




\begin{tabular}{|c|c|c|c|c|c|c|}
\hline No. & $\begin{array}{l}\text { KBAs } \\
\text { ( }{ }^{*} \text { sites holding narrow } \\
\text { endemic species) }\end{array}$ & $\begin{array}{l}\text { Bird species } \\
\text { that trigger } \\
\text { the Vulnera- } \\
\text { bility criterion }\end{array}$ & $\begin{array}{l}\text { Bird species } \\
\text { that trigger the } \\
\text { Irreplaceabillity } \\
\text { criterion (d - } \\
\text { maintaining } \\
1 \% \text { of } \\
\text { global } \\
\text { population) }\end{array}$ & $\begin{array}{l}\text { Plant species } \\
\text { that trigger the } \\
\text { Irreplaceabillity } \\
\text { criterion - Highly } \\
\text { restricted-range } \\
\text { species (range }<500 \\
\mathrm{~km}^{2} \text { ) }\end{array}$ & $\begin{array}{l}\text { Plant species } \\
\text { that trigger the } \\
\text { Irreplaceabillity } \\
\text { criterion - Restri- } \\
\text { cted range species } \\
\text { (range }<5,000 \mathrm{~km}^{2} \text { ) } \\
\text { (Threshold }-5 \% \text { of } \\
\text { the global popula- } \\
\text { tion or one of the } 5 \\
\text { best sites in MK) }\end{array}$ & $\begin{array}{l}\text { Plant species that trigger } \\
\text { the Irreplaceabillity } \\
\text { criterion - Species } \\
\text { with large but clumped } \\
\text { populations } \\
\text { (Threshold }-5 \% \text { of the } \\
\text { global population or one } \\
\text { of the } 5 \text { best sites in MK) }\end{array}$ \\
\hline 29 & $\begin{array}{l}\text { KBA Pchinja-Petroshnica- } \\
\text { Kriva Reka (84938 ha) } \\
\text { = IBA Pchinja River-river } \\
\text { Petrošnica-Kriva Reka }\end{array}$ & $\begin{array}{l}\text { Neophron } \\
\text { percnopterus } \\
\text { (3-4 pairs) } \\
\text { (EN) }\end{array}$ & & & & \\
\hline 30 & $\begin{array}{l}\text { KBA Pelagonia (113164 ha) } \\
=\text { IBA Pelagonia }\end{array}$ & & $\begin{array}{l}\text { Falco naumanni } \\
\text { (750-850 pairs) } \\
\text { (LC) }\end{array}$ & & & \\
\hline 31 & $\begin{array}{l}\text { KBA Pelister (17158 ha) } \\
=\text { IPA Pelister }\end{array}$ & & & $\begin{array}{l}\text { Dianthus myrtinervius } \\
\text { Griseb. } \\
\text { Alchemilla pelisterica } \\
\text { Pawl. }\end{array}$ & $\begin{array}{l}\text { Pedicularis } \\
\text { limnogena A. Kerner } \\
\text { Alkanna pulmonaria } \\
\text { Griseb. }\end{array}$ & $\begin{array}{l}\text { Trifolium pilczii Adam. } \\
\text { Sempervivum octopodes } \\
\text { Turill (half of the } \\
\text { population). Soldanella } \\
\text { pindicola Hausskn. } \\
\text { Viola eximia Form. }\end{array}$ \\
\hline 32 & $\begin{array}{l}\text { KBA Pogana-Gjavato (5402 } \\
\text { ha) = IPA Churchulum - } \\
\text { Bogdanci }\end{array}$ & & & & $\begin{array}{l}\text { Astragalus } \\
\text { physocalyx Fisch. }\end{array}$ & $\begin{array}{l}\text { Isoetes phrygia (Boiss.) } \\
\text { Hausskn. }\end{array}$ \\
\hline 33 & $\begin{array}{l}\text { KBA Radusha-Zheden } \\
\text { (9291 ha) } \\
\text { = IPA Radusha-Zeden }\end{array}$ & & & & $\begin{array}{l}\text { Genista nissana } \\
\text { Petrovic } \\
\text { Potentilla visianii } \\
\text { Pancic }\end{array}$ & $\begin{array}{l}\text { Centaurea kosaninii Hayek } \\
\text { Astragalus baldaccii } \\
\text { Degen } \\
\text { Tulipa scardica Bornm. }\end{array}$ \\
\hline 34 & $\begin{array}{l}\text { KBA Shar Planina* (50163 } \\
\text { ha) } \\
\text { = IPA Shara Mountain } \\
\text { (also overlaps with IBA Shar } \\
\text { Planina, which does not } \\
\text { qualify as KBA) }\end{array}$ & & & $\begin{array}{l}\text { Dianthus scardicus } \\
\text { Košanin } \\
\text { Potentilla doerfleri } \\
\text { Wettst. } \\
\text { Silene schmuckeri } \\
\text { Boiss. }\end{array}$ & $\begin{array}{l}\text { Ranunculus degenii } \\
\text { Kummerle \& Jav. } \\
\text { Sempervivum } \\
\text { kosaninii Praeger }\end{array}$ & $\begin{array}{l}\text { Eryngium serbicum Pancic } \\
\text { Alkanna noneiformis } \\
\text { Griseb. } \\
\text { Narthecium scardicum } \\
\text { Košanin } \\
\text { Soldanella pindicola } \\
\text { Hausskn. }\end{array}$ \\
\hline 35 & $\begin{array}{l}\text { KBA Skopska Crna Gora } \\
(10023 \text { ha) } \\
=\text { IPA Skopska Crna Gora }\end{array}$ & & & & $\begin{array}{l}\text { Genista nissana } \\
\text { Petrovic }\end{array}$ & $\begin{array}{l}\text { Alkanna noneiformis } \\
\text { Griseb. } \\
\text { Alkanna stribrnyi Velen. }\end{array}$ \\
\hline 36 & $\begin{array}{l}\text { KBA Stogovo* (11577 ha) } \\
=\text { IPA Stogovo }\end{array}$ & & & $\begin{array}{l}\text { Sempervivum } \\
\text { thompsonianum Wale }\end{array}$ & & Trifolium pilczii Adam. \\
\hline 37 & $\begin{array}{l}\text { KBA Suva Gora (21101 ha) } \\
=\text { IPA Suva Gora }\end{array}$ & & & & & $\begin{array}{l}\text { Centaurea grbavacensis } \\
\text { (Rohl.) Stoy. \& Acht. }\end{array}$ \\
\hline 38 & $\begin{array}{l}\text { KBA Taorska Klisura } 1 \\
\text { (1535 ha) } \\
\text { = IPA Taorska Klisura } \\
\text { (does not overlap with IBA } \\
\text { Taorska Klisura) }\end{array}$ & & & & $\begin{array}{l}\text { Anchusa } \\
\text { macedonica Degen } \\
\text { \& Dorfl. } \\
\text { Sempervivum } \\
\text { kindingeri Adam. }\end{array}$ & $\begin{array}{l}\text { Alkanna noneiformis } \\
\text { Griseb. } \\
\text { Alkanna stribrnyi Velen. }\end{array}$ \\
\hline 39 & $\begin{array}{l}\text { KBA Taorska Klisura } 2 \\
(2538 \text { ha) } \\
\text { = IBA Taorska Klisura }\end{array}$ & $\begin{array}{l}\text { Neophron } \\
\text { percnopterus } \\
(1-2 \text { pairs) (EN) }\end{array}$ & & & & \\
\hline 40 & $\begin{array}{l}\text { KBA Tikveshija (18696 ha) } \\
=\text { IBA Tikvesh Region }\end{array}$ & $\begin{array}{l}\text { Neophron } \\
\text { percnopterus } \\
\text { (2 pairs) (EN) }\end{array}$ & & & & \\
\hline 41 & $\begin{array}{l}\text { KBA Treskavec* }(3649 \text { ha }) \\
=\text { IPA Prilep-Pletvar }\end{array}$ & & & $\begin{array}{l}\text { Armeria vandasii } \\
\text { Hayek } \\
\text { Asplenium } \\
\text { macedonicum Kümm. } \\
\text { Centaurea marmorea } \\
\text { Bornm. et Soška } \\
\text { Moehringia minutiflora } \\
\text { Bornm }\end{array}$ & $\begin{array}{l}\text { Alyssum doerfleri } \\
\text { Degen } \\
\text { Anchusa } \\
\text { macedonica Degen } \\
\text { \& Dorfl. } \\
\text { Silene viscariopsis } \\
\text { Bornm. }\end{array}$ & $\begin{array}{l}\text { Eryngium serbicum Pancic } \\
\text { Centaurea grbavacensis } \\
\text { (Rohl.) Stoy. \& Acht. } \\
\text { Alkanna noneiformis } \\
\text { Griseb. } \\
\text { Anchusa serpentinicola } \\
\text { Rech.f. }\end{array}$ \\
\hline 42 & $\begin{array}{l}\text { KBA Vodno (2199 ha) } \\
=\text { IPA Vodno }\end{array}$ & & & & $\begin{array}{l}\text { Genista nissana } \\
\text { Petrovic }\end{array}$ & $\begin{array}{l}\text { Alkanna noneiformis } \\
\text { Griseb. }\end{array}$ \\
\hline
\end{tabular}


Sofia, 530pp (in Bulgarian).

Langhammer, P.F., M.I. Bakarr, L.A. Bennun, T.M. Brooks, R.P. Clay, W. Darwall, N. De Silva, G.J. Edgar, G. Eken, L.D.C. Fishpool, G.A.B. da Fonseca, M.N. Foster, D.H. Knox, P. Matiku, E.A. Radford, A.S.L. Rodrigues, P. Salaman, W. Sechrest \& A.W. Tordoff (2007). Identification and Gap Analysis of Key Biodiversity Areas: Targets for Comprehensive Protected Area Systems. IUCN, Gland, Switzerland.

Levkov, Z., S. Krstic, D. Metzeltin \& T. Nakov (2007). Diatoms of Lakes Prespa and Ohrid (Macedonia). Iconographia Diatomologica 16: 1-603.

Levkov, Z. (2009). Amphora sensu lato, pp. 1-916. In: Lange-Bertalot, H. (ed.). Diatoms of Europe, Diatoms of the European Inland waters and comparable habitats-Vol-5. A.R.G. Gantner Verlag K.G.

Matevski, V. (2010). The Flora of the Republic of Macedonia, MANU, Skopje, 2(1): 1-187 (in Macedonian).

Melovski, Lj., V. Matevski, M. Kostadinovski, M. Karadelev, N. Angelova \& E.A. Radford (2010). Important Plant Areas in the Republic of Macedonia. Special issue of Macedonian Ecological Society, Vol. 9, Skopje, 128pp. (In Macedonian)

Melovski, Lj., S. Hristovski, R. Brajanoska, M. Velevski, A. Sarov \& V. Avukatov (2011). Development of the representative protected areas' system in the Rpublic of Macedonia based on GIS methodology. Proceedings of the conference "Nature Protection in XXI century", 20-23 September, Zhabljak, Montenegro. Book I, pp. 95-109, Nature Conservation Institute of Montenegro and the Ministry of Sustainable Development and Tourism of Montenegro.

Micevski, B. (2002/2003). New species of birds for the Republic of Macedonia. Godišen Zbornik Biologija 55/56: 55-73.

Micevski, K. (1985). The Flora of the Republic of Macedonia, MANU, Skopje, 1(1): 1-152 (in Macedonian).

Micevski, K. (1993). The Flora of the Republic of Macedonia, MANU, Skopje, 1(2): 153-39 (in Macedonian).

Micevski, K. (1995). The Flora of the Republic of Macedonia, MANU, Skopje, 1(3): 503-548 (in Macedonian).

Micevski, K. (1998). The Flora of the Republic of Macedonia, MANU, Skopje, 1(4): 781-1113 (in Macedonian).

Micevski, K. (2001). The Flora of the Republic of Macedonia, MANU, Skopje, 1(5): 1121-1430 (in Macedonian).

Micevski, K. (2005). The Flora of the Republic of Macedonia, MANU, Skopje, 1(6): 1437-1715 (in Macedonian).

Ministry of Environment and Physical Planning (2004). Biodiversity Strategy and Action Plan. MoEPP, Skopje.

Plantlife International (2004). Identifying and conserving the world's most Important Plant Areas. A guide to implementing target 5 of the CBD. Plantlife, Salisbury UK.

Radford, E.A. \& B. Odé (eds.) (2009). Important Plant Areas in South East Europe conserving priority sites for plants. Plantlife International, UK.

Stattersfield, A.J., M.J. Crosby, A.J. Long \& D.C. Wege (1998). Endemic Bird Areas of the World: Priorities for Biodiversity Conservation. Cambridge, UK: BirdLife International.

Strid, A. \& K. Tan (eds.) (1991). Mountain Flora of Greece-Vol. II. Edinburgh University Press, Edinburgh, 974pp.

Strid, A. \& K. Tan (eds.) (1997). Flora Hellenica-Vol. I. Koeltz Scientific Books, Köenigstein, 547pp.

Velevski, M., B. Hallmann, B. Grubač, E. Lisičanec, E. Stoynov, T. Lisičanec, V. Avukatov, L. Božič \& B. Stumberger (2010). Important Bird Areas in Macedonia: Sites of global and European importance. Acrocephalus 147: 181-282.

Walter, K.S. \& H.J. Gillett (eds.) (1998). 1997 IUCN Red List of Threatened Plants. IUCN - The World Conservation Union.
Author Details: LJuPCo MelovskI is professor at the Institute of Biology, Faculty of Natural Sciences and Mathematics, and President of the Macedonian Ecological Society. His field of expertise is forest ecology and plant conservation. He was leader of the project for identification of the Important Plant Areas in Macedonia.

MetodiJa Velevski is an ornithologist at the Macedonian Ecological Society, where he works on vulture conservation and has led the initiative for identification of Important Bird Areas in Macedonia.

VLADO MATEVSKI is professor at the Institure of Biology, Faculty of Natural Sciences and Mathematics and member of the Macedonian Academy of Sciences and Arts. His field of expertise include plant taxonomy and plant communities.

VAsko Avukatov and Aleksandar Sarov are GIS specialists in the Macedonian Ecological Society.

Author Contribution: LjM responsible for background IPA identification and writing the paper; MV responsible for background IBA identification and writing the paper; VM responsible for background IPA identification; VA mapping of species in the IPAs and IBAs and developing respective background shapefile layers; AS performing KBA GIS analyses.

Acknowledgements: The authors are deeply grateful to the financial support provided by both the MAVA foundation, for the identification and delineation of IPAs in Macedonia, and the Frankfurt Zoological Society, Black Vulture Conservation Foundation and the Vulture Conservation Foundation, for the long-term study and monitoring of Macedonia's raptors' populations. In addition, we thank Plantlife International and BirdLife International for their support in the identification and delineation of IPAs and IBAs respectively, and for proof reading the English manuscript. We are also grateful to Macedonian Ecological Society for providing all necessary shape-file layers to compile this paper. 